\title{
Milliliter per Hour per Milligram per Kilogram per Day
}

National Cancer Institute

\section{Source}

National Cancer Institute. Milliliter per Hour per Milligram per Kilogram per Day. NCI

Thesaurus. Code C120779.

A unit of concentration equal to milliliter per hour divided by milligram per kilogram per day. 